\section{RESEARCH CAPACITY}

\section{World Bank} invests in Africa

\author{
Grassroots science initiative \\ receives US\$280 million.
}

\section{BY LINDA NORDLING}

A World Bank scheme aimed at building research capacity in Africa has announced a third, and probably final, investment worth at least US\$280 million. The initiative loans money to African governments, and has set up 46 education and research centres in 17 African countries - but some worry what will happen once the bank's money runs out.

"I see a big challenge when the funding ends," says Patrick Ogwang, who leads a traditional-medicine research centre funded by the initiative, at Mbarara University in Uganda. He is eyeing industry partnerships as a source of future cash, but says that competition is fierce.

The World Bank launched the African Centres of Excellence (ACE) initiative in 2014 with $\$ 165$ million in loans; it created 22 centres in West and central African nations. Two years later, the bank approved $\$ 148$ million to create 24 hubs in eastern and southern African countries. The third round, announced on 31 August, pushes the bank's total investment past $\$ 500$ million. It again targets West and central Africa, and French development agency the AFD may add another $\$ 50$ million.

The centres focus on local research challenges such as plant breeding and infectious diseases, and have created jobs for hundreds of scientists and trained thousands of graduate students. Centres are eventually expected to sustain themselves with funding from governments, charities and industry. It's important that the centres move towards this, says World Bank economist Andreas Blom, who leads the programme, but the third round of loans will offer "weaning off" funding for existing centres in West and central Africa, and pay for new ones.

Critics of the scheme say that it has allowed governments to delay making substantive national investments in research. Governments have 40 years to repay the money at low or zero interest. "Many African governments, with short political life spans, are not really concerned about who will pay and how," says John Mugabe, an expert on science policy in Africa at the University of Pretoria in South Africa.

Representatives from the Ghanaian and Nigerian governments told Nature that the ACE loans complement their plans for national funding. In Ghana, higher-quality research proposals will reach the country's national research fund thanks to the scheme, says Mohammed Salifu, executive secretary of Ghana's National Council for Tertiary Education. -

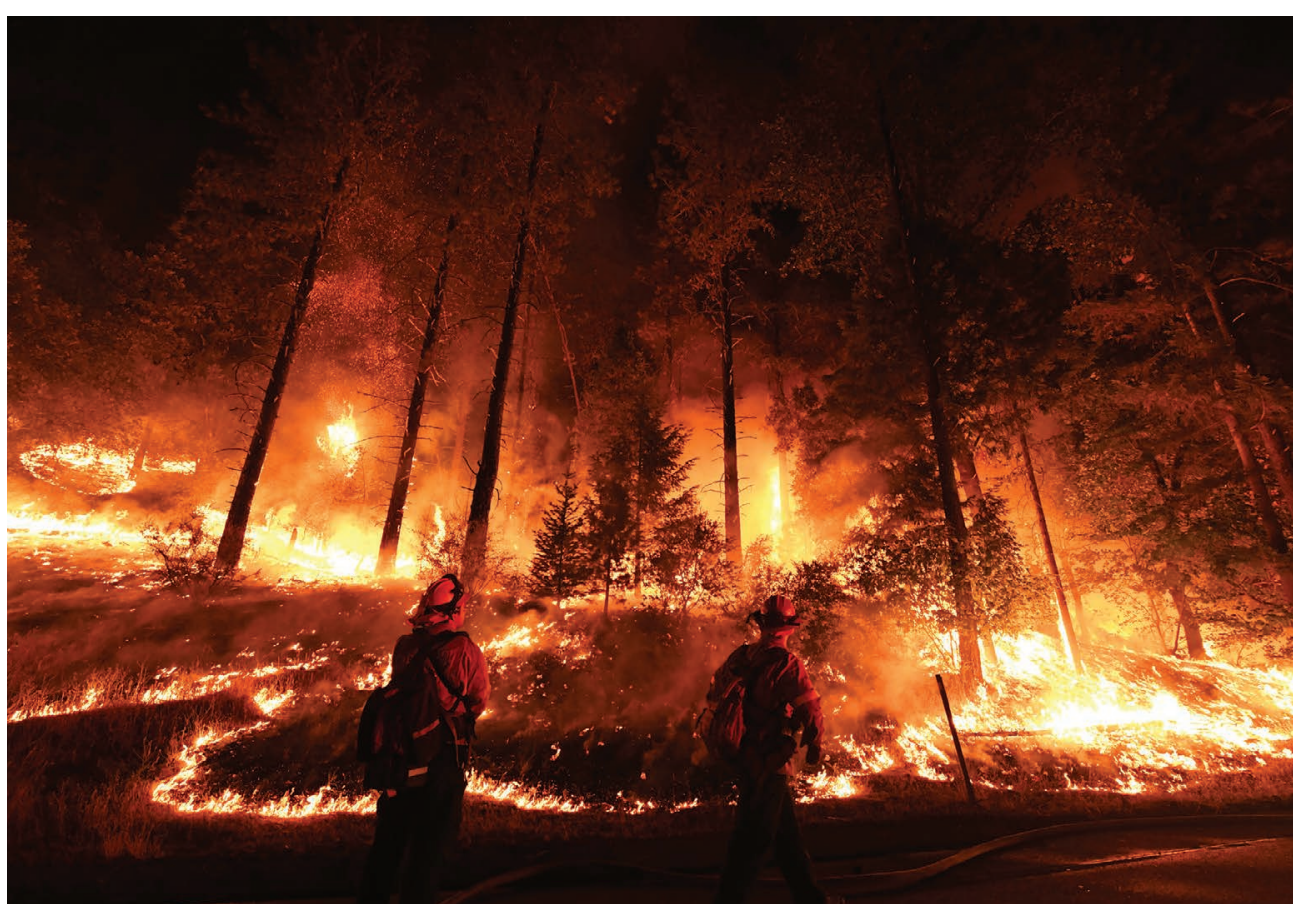

Firefighters battle a blaze near Redding, California, in July.

\title{
ECOLOGY
}

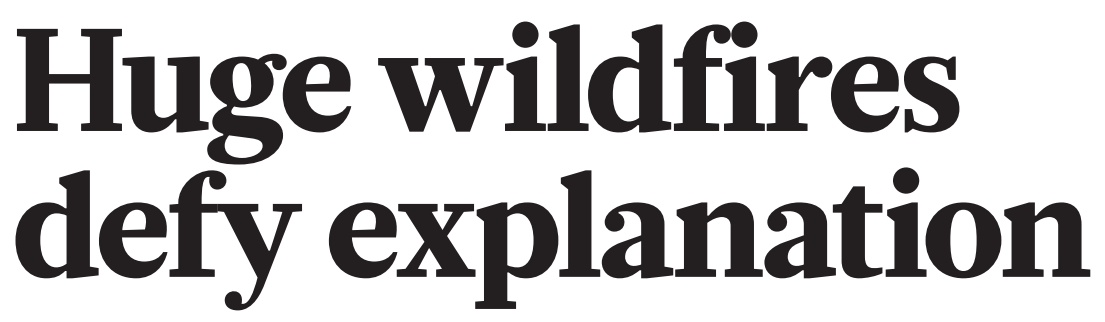

\section{Researchers scramble to improve wildfire models as blazes become larger and less predictable.}

\section{BY JEFF TOLLEFSON}

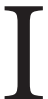
n California, where the state's largest wildfire on record continues to burn, fires are getting bigger and less predictable - so much so that scientists are struggling to model them. Now, two research projects under way in the state are aiming to revamp the models that scientists, first responders and policymakers use to understand these dangerous and costly disasters.

One, slated to wrap up in the next few months, looks at how specific environmental factors such as extreme winds affect fires. The other, officially launched on 30 August, focuses on how wildfires will change in the coming decades as the climate warms.

"Something is definitely different, and it raises questions about how much we really know," says Max Moritz, a fire scientist at the University of California, Santa Barbara.

The efforts come against a backdrop of abnormal fire seasons around the world. The giant California fire has torched about 166,000 hectares since late July, and continues to burn in the northern part of the state. British Columbia in Canada is now experiencing its worst fire season on record (see 'Scorched earth'). And in late July, after
"We need to refocus some of our research efforts on characterizing the kinds of fire behaviour that cause us the most grief." weeks of intense heat and some of the lowest rainfall totals since the late nineteenth century, officials in Sweden were battling roughly 50 wildfires across the country.

Researchers have been at a loss to explain a flurry of unusual fire behaviour in California in recent years: wildfires that burn hot throughout the night instead of settling down, as many used to; blazes that race down hillsides faster than before; and fires that torch suburban neighbourhoods that were once considered safe from such 